\title{
Approach to disability in a population from the Argar Culture
}

\author{
Aproximación a la discapacidad en una población de la cultura de El Argar
}

\author{
María G. Roca (*) \\ Sylvia Jiménez-Brobeil $(*)$ \\ Ihab Al Oumaoui (*) \\ Juan M. Tristán (**) \\ Fernando Molina (***)
}

\begin{abstract}
A new research field is being developed on disability in Archaeology and Physical Anthropology, which is investigated in this article in the context of the Argaric Culture. More than 200 skeletons, coming from sites in Granada province (Castellón Alto, Fuente Amarga, Cuesta del Negro, Terrera del Reloj and Cerro de la Encina), were studied, finding four with signs of physical impairment: one male and one female who must both have used a walking aid, and two males with shoulder dislocations. All four individuals were buried according to Argaric Culture rituals, beneath their dwellings, indicating that they were not socially rejected. Nevertheless, further insight into disability in this culture is hampered by the limited biological and archaeological data available.
\end{abstract}

\section{RESUMEN}

La discapacidad, entendida como la consideración de una persona con invalidez por parte de su comunidad, constituye un nuevo campo de investigación en Arqueología y Antropología Física. Aquí se investiga este concepto en el marco de la cultura de El Argar. Se han estudiado más de 200 esqueletos procedentes de yacimientos de la provincia de Granada (Castellón Alto, Fuente Amarga, Cuesta del Negro, Terrera del Reloj y Cerro de la Encina)

(*) Laboratorio de Antropología, Facultad de Medicina, Universidad de Granada. Avda. de Madrid 11. 18071 Granada. E-mail: mgroca@gmail.com; jbrobeil@ugr.es; oumaoui@gmail.com

(**) Dpto. de Enfermería, Facultad de Ciencias de la Salud, Universidad de Granada. Avda. de Madrid s/n. 18071 Granada. E-mail: jtristan@ugr.es

(***) Dpto. de Prehistoria y Arqueología, Facultad de Filosofía y Letras, Universidad de Granada. Campus Universitario de Cartuja. 18071 Granada. E-mail: molinag@ugr.es

Received: 31-V-2011; accepted: 6-X-2011. entre los cuales cuatro muestran señales de invalidez: un hombre y una mujer que debieron haber requerido ayuda para caminar y dos varones con luxaciones de hombro. Los cuatro individuos fueron enterrados según los rituales de la cultura argárica, bajo sus propias viviendas, lo que indica que no fueron rechazados socialmente. Sin embargo, no se puede profundizar sobre la concepción de la discapacidad en esta cultura puesto que los datos arqueológicos y biológicos son muy limitados.

Key words: Disability; Physical impairment; Archeology of death; Bronze Age; Recent Prehistoric; Iberian Peninsula.

Palabras clave: Discapacidad; Invalidez; Arqueología de la muerte; Edad del Bronce; Prehistoria Reciente; Península Ibérica.

\section{INTRODUCTION}

There has been considerable recent interest in the study of disability in the past, largely focussed on the role of physically impaired individuals and their survival in the group and on the possible presence of some type of care (Berkson 2004; Tarlow 2000; Thorpe 2008; Winzer 1997). The most ancient cases that have been studied in Palaeoanthropology are those found in Dmanisi (Lordkipanidze et al. 2005), Atapuerca (Gracia et al. 2009) and Shanidar (Trinkaus and Zimmerman 1982) among others. Many of these skeletons are individuals who reached a relatively old age despite physical impairment. They would have had limited ability to contribute to hunting or gathering activities and would have died even earlier without substantial help and care from their companions 
(Roberts and Manchester 2007; Tarlow 2000). Nevertheless, the fact that an individual lived longer than expected does not necessarily imply that he/she received care (DeGusta 2002; Dettwyler 1991), and his/her position within the social group cannot be determined from archaeological evidence alone (Dettwyler 1991). Moreover, any evidence that an individual was cared for does not reveal the attitudes or rationale underlying this treatment (Finlay 1999; Tarlow 2000). There are further reports on individuals with physical impairment in recent Prehistory and even more in Classical Antiquity and Mediaeval times, and the difficulty in all cases is to determine how they were considered in their societies (Buquet-Marcon et al. 2009; Darton 2010; Dickel and Doran, 1989; Hawkey 1998; Lieverse et al. 2008; Oxenham et al. 2009; Pany and Tescher-Nicola 2007; Phillips and Sivilich 2006; Van der Sanden 1996).

Palaeopathology studies can offer biological evidence of physical impairment but cannot provide direct evidence of disability, i.e., the relationship between impaired individuals and their societies (Shakespeare 1999). Disability is a cultural understanding or social construct that leaves no biological traces (Reid-Cunningham 2009; Tarlow 2000). In fact, a major shortcoming of the study of disability in past populations is the difficulty of avoiding the application of current concepts of disability to other times (Cross 1999; Roberts 1999). For instance, there is a tendency to consider impaired individuals to be permanently disabled in our Western culture, which focuses on economical and social factors in relation to the ability to work. However, what is now medically considered a disability may have been viewed very differently in the past. In other words, injury and impairment do not necessarily equate with social exclusion (Anderson and Carden-Coyne 2007; Cross 1999). On the other hand, infertility may have been regarded as more disabling than any other physical problem in past societies (Tarlow 2000). It should be borne in mind that cultures differ in their conception of disability (ReidCunningham 2009). Thus, although a skeleton shows severe lesions that might now be considered a disability, it is impossible to make concrete statements about how much these lesions may have affected the individual's life (Anderson and Carden-Coyne 2007; Metzler 1999).

Because paleopathologists can only study injuries and abnormalities that affect the skeleton, no data are available on other problems, such as sight deficiencies or blindness, which affect a large number of individuals. It can also be difficult to determine whether a case of impairment is congenital or acquired. Furthermore, it is difficult to establish from the archaeological records whether "different" children were victims of infanticide or abandonment, given the fragility of children's bones (Molleson 1999).

In individuals integrated within a social group, with impairments produced by an accident or disease, their previous social status would be crucial for their future. Thus, in the Middle Ages, an individual contracting leprosy would be socially rejected, whereas a traumatic injury would not automatically relegate the sufferer to the ranks of the impoverished and destitute (Knüsel 1999), because other abilities that he or she possessed could make the impairment irrelevant (Tarlow 2000). As we can see, recognising disablement in the archaeological record is truly difficult because we have only biological evidence and some cultural clues as to how the individuals were considered by the social group at the time of death.

Taking into account these limitations, we have addressed the issue of disability in the Bronze Age culture, a period of great social complexity. Our main objective was to identify injuries and abnormalities that could cause physical impairment and to assess whether this condition could be considered a disability and whether these individuals were accepted or marginalised by their social group.

\section{MATERIAL AND METHODS}

The study population belongs to the Argar Culture, typical of the South-East of the Iberian Peninsula during the Bronze Age, which was characterized in Europe by sociopolitical groups in which status and power were extremely important (Harding 2000). All of these groups share in common the emergence of elites, a high level of political centralization, the competitive exchange of goods and ideas and a marked social differentiation, alongside concepts of leadership and hierarchical society (Cámara and Molina 2006; Chapman 2003; Chapman 2008; Guilaine and Zammit 2002; Harding 2000). The social dynamics of this period also included attributed social status, hereditary privileges and power disparities. The different status of the members of a 
community is expressed in their access to basic resources and power and in differences in their habitat and funerary patterns (Aranda and Esquivel 2007; Cámara and Molina 2006; Castro Martínez et al. 1993-1994; Lull 2000; Molina and Cámara 2004, 2009).

The Argar Culture has been considered the most important Bronze Age phenomena in the Western Mediterranean (Siret and Siret 1890). Populations lived in small villages on top of steep hills dominating fertile valleys. There usually was a walled acropolis at the highest point, surrounded by dwellings on stepped terraces. The economy was based on agriculture and livestock, with some mining activity. The burials were beneath the dwellings with skeletons in flexed position. Differences in the values of funeral goods are interpreted as signs of distinct social classes. There is an elite, characterized by gold and silver funeral goods, an intermediate class, and an underclass with very poor goods or none at all (Cámara and Molina 2006; Castro Martínez et al. 1993-1994; Lull 1983, 2000; Molina et al. 1986; Molina and Cámara 2004, 2009). The goods differed according to the sex of the individuals, demonstrating a clear differentiation of roles between the sexes (Al Oumaoui et al. 2004; Jiménez-Brobeil et al. 2004). The presence of infant burials with very rich goods indicates that social status was assigned from birth (Molina 1983).

Our group has studied more than 200 individuals from the numerous archaeological excavations performed in Argar Culture sites in the province of Granada: Castellón Alto (Galera), Fuente Amarga (Galera), Cuesta del Negro (Purullena), Terrera del Reloj (Dehesas de Guadix) and Cerro de la Encina (Monachil) (Fig. 1). The degree of preservation is highly variable, preventing the observation of possible lesions in numerous individuals (Battles 2009). In the archaeological records of this sample, no individual was buried outside the usual funerary rituals of this culture, and no child showed features that indicated abandonment. We found no cases of congenital abnormality that could lead to physical impairment or cases of poliomyelitis. Although numerous cases of severe osteoarthritis were detected, these were not considered because the clinical severity of bone lesions does not consistently correspond with physical impairment, and pain is highly subjective. Moreover, osteoarthritis is a characteristic of aging. Although the elderly tend to be marginalised or rejected and considered as disabled in contemporary western society, this is not the case in other cultures or in past times in our culture, especially when life expectancy was very short and age could be a sign of social prestige. Cases of consolidated fractures without deformation have also been excluded from our study, since they may only produce impairment during the healing period. Finally, we selected four cases with lesions that not correctly healed. The sex and age of these individuals are determined by pelvic and skull morphology, pubic symphyses, sternal rib ends and cranial suture (Byers 2002; Krogman and Isçan 1986; Suchey and Brooks 1988).

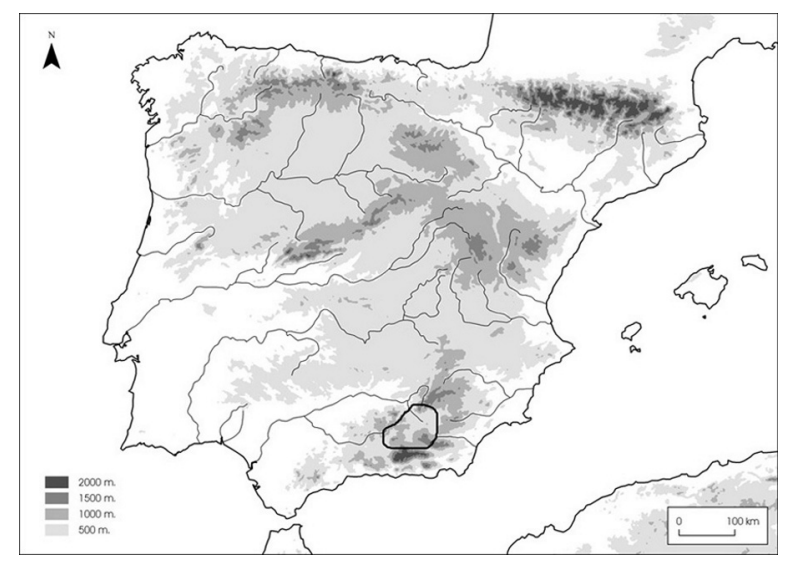

Fig. 1. Iberian Peninsula. The studied sites are located in the marked area (province of Granada): Castellón Alto and Fuente Amarga (Galera), Cuesta del Negro (Purullena), Terrera del Reloj (Dehesa de Guadix), and Cerro de la Encina (Monachil).

\section{CASE REPORTS AND DISCUSSION}

\section{Case 1}

This skeleton comes from the Castellón Alto site near the village of Galera (Granada) and was found in 2002 in burial n. ${ }^{\circ} 112$. The funerary goods comprised a small pottery object and a meat offering (ovicaprid bone), indicating a medium social level (Molina et al. 2003; RodríguezAriza and Ruiz Sánchez 1992). Meat offerings, generally from goat, sheep or cow, denote a commensality ritual characteristic of the Argar Culture (Aranda and Esquivel 2007). 


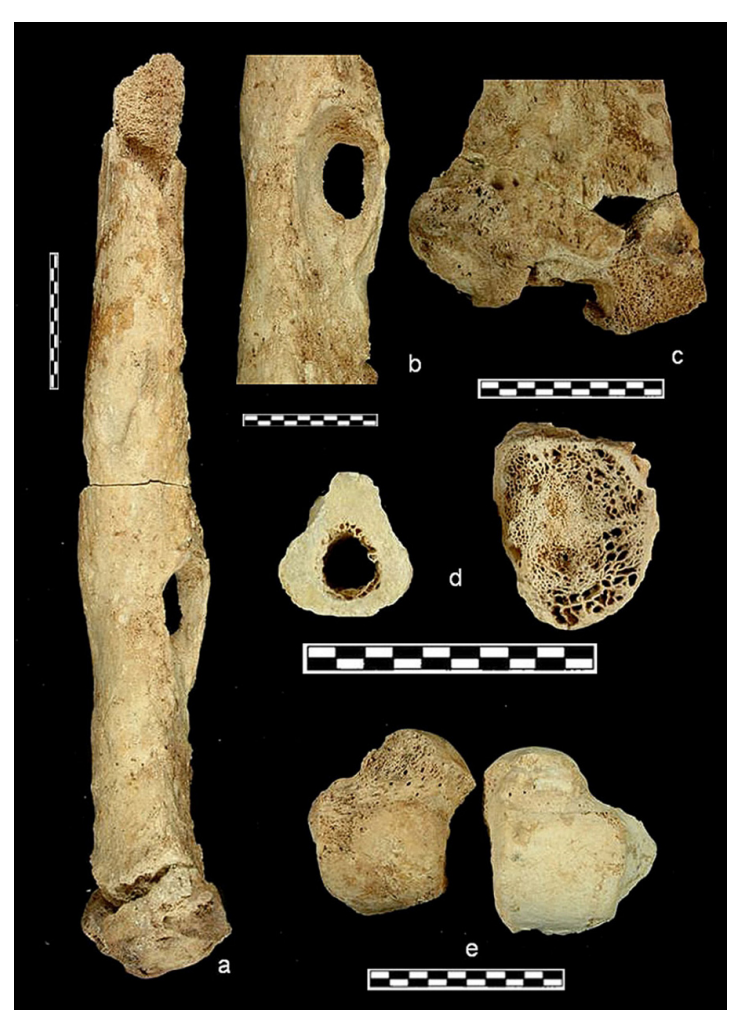

Fig. 2. Settlement of Castellón Alto (Galera, Granada). Case 1, 35-39 years-old male, burial n. ${ }^{\circ} 112$ : a. Left femoral diaphysis, lateral view; b. Detail of left femoral diaphysis in posterior view; c. Detail of left distal epiphysis; d. Sections of normal right femur and of pathological left femur; e. Upper view from the tali. All photos: S. Jiménez-Brobeil.

He was a 35-39 year-old male with a medium degree of preservation and presents signs of strong muscle development in the upper extremities and weak development in the lower members (Al Oumaoui et al. 2004). He has two healed traumatisms in the ribs, mild osteoarthritis in the lumbar spine and Schmorl's nodes in L1, L2, L3 and L4. Lesions on the left femur could be attributed to osteomyelitis (Fig. 2a-d). X-ray studies revealed no signs of trauma in this femur, therefore the infection may have initiated in a soft tissue injury and reached the bone via the blood. A severe periostitis was detected on the left fibula and on preserved fragments of the tibia, which may indicate extension of the infection to the entire lower limb. Signs of severe osteoarthritis were observed in the left knee (Fig. 2c).

The left talus shows a varus deformation of the head and neck (Fig. 2e) that may be related to the other lesions, since the thigh must have been very large, obliging him to walk with his foot turned inwards. This position of his lower limb and his upper extremity muscle development suggests that this man walked with the aid of crutches or sticks. The right femur shows a popliteal or Baker's cyst (Fig. 3 upper). A Baker's cyst can be caused by herniation of the knee joint capsule to the back of the knee. This commonly occurs with a tear in the meniscal cartilage of the knee and is related to a trauma (Johnson et al. 1997). A large cyst may cause some discomfort or stiffness but generally has no other symptoms. This lesion may be the result of overloading the right leg while walking.

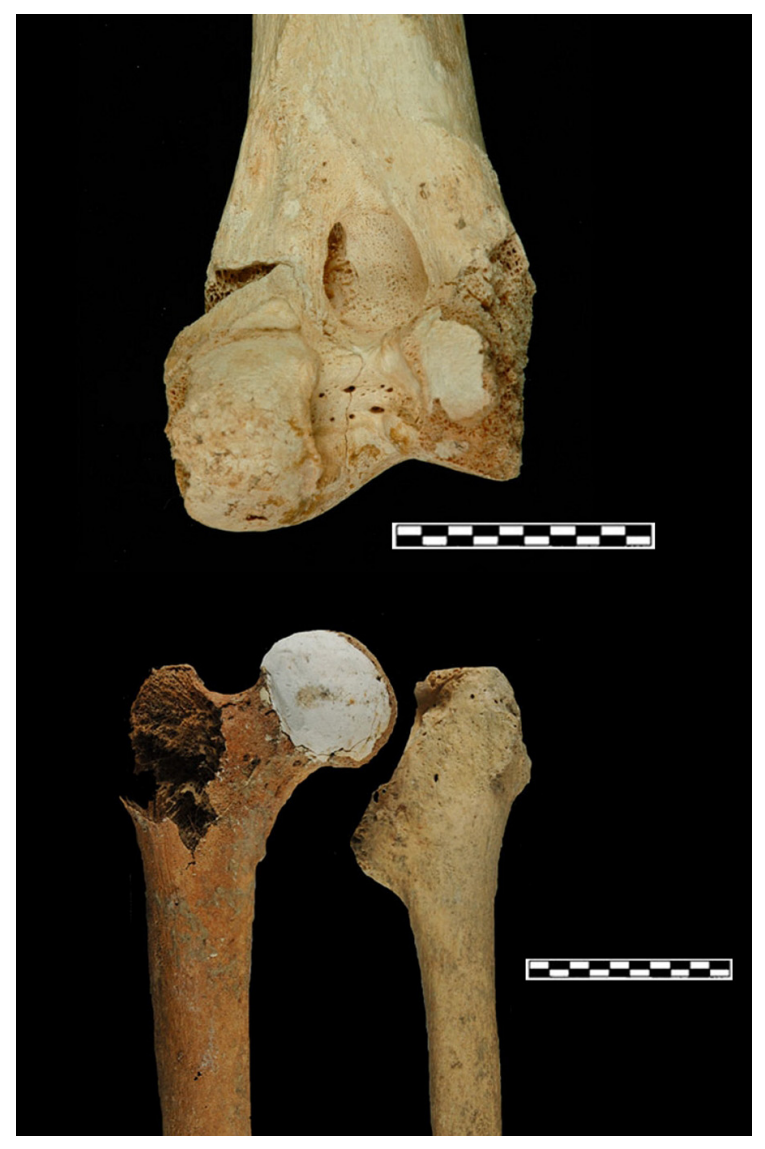

Fig. 3. Settlement of Castellón Alto (Galera, Granada). Upper Case 1, 35-39 years-old male, burial n. ${ }^{\circ} 112$ : Detail of the popliteal or Baker's cyst of right distal epiphysis. Down. Case 2, 41-60 years-old female, burial n. ${ }^{\circ} 30$ : Detail of femoral proximal epiphysis in anterior view. All photos: S. Jiménez-Brobeil. 


\section{Case 2}

This skeleton also comes from the Castellón Alto site. It was found in 1983 in burial n. ${ }^{\circ} 30$ that contained the remains of a male and a female. The present case is a mature woman, aged between 41 and 60 years, with a poor degree of preservation. The funerary goods comprised a pottery object, bronze awl and meat offering, indicating a medium social level in this community (Molina et al. 2003; Rodríguez-Ariza and Ruiz Sánchez 1992).

The individual shows ante-mortem loss of some teeth, caries, some badly worn teeth and signs of periodontal disease. The upper extremities show signs of strong muscle development (Fig. 4a) (Al Oumaoui et al. 2004). A consolidated fracture can be observed in the distal epiphysis of the left radius and a mild osteoarthritis in the thoracic and lumbar regions of the spine. The lower extremities are slender and show less signs of muscular development in comparison to the upper extremities. The left femoral head is separated from the femoral neck and was found inside the acetabulum (Figs. 3 down and $4 \mathrm{~b}, \mathrm{c})$; the head shows a small area of necrosis on the articular surface while the femoral neck had undergone complete bone remodelling.

Fracture of the femoral head is a severe and relatively uncommon injury, even nowadays. Most patients with a femoral head fracture are young people with posterior dislocation of the hip joint after a high-energy trauma in which the knee strikes a hard surface and the force is propagated up the leg. The head fracture results from the impact or from shearing by the acetabulum (Koval and Zuckerman 2002). The hip, when flexed at $90^{\circ}$ and slightly adducted, is at particular risk of dislocation. The fracture and associated complications (necrosis, bone remodelling, heterotopic ossification) indicate that this woman must have had considerable difficulties in walking, which may have led her to over-use her upper extremities, e.g. by using walking sticks or crutches. This proposition is supported by the signs of greater muscle development in the upper versus lower extremities.

\section{Case 3}

This skeleton was found in 1983 at La Terrera del Reloj site in Dehesas de Guadix (Granada)

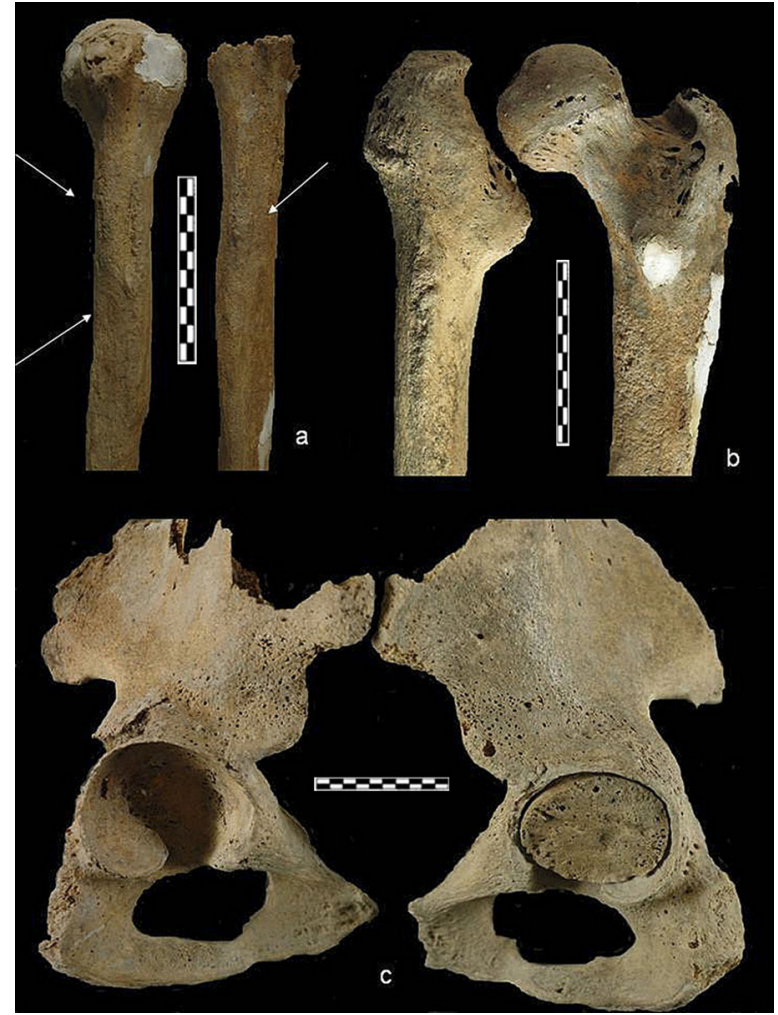

Fig. 4. Settlement of El Castellón Alto (Galera, Granada). Case 2, 41-60 years-old woman, burial n. ${ }^{\circ} 30$ : a. Humeri. The arrows indicate muscular attachments; b. Femora. Detail of proximal epiphysis in posterior view; c. Coxae with left femoral head in acetabulum. All photos: S. Jiménez-Brobeil.

(Molina et al. 1986). It comes from burial n. ${ }^{\circ} 2$. The funerary goods comprised a pottery bowl, bronze axe and necklace, denoting high social status. The skeleton, which is in an intermediate state of preservation (Al Oumaoui and JiménezBrobeil 2003), belongs to a male who died at the age of around 24 years. The skeleton evidences dental disease, cribra orbitalia and a mild traumatic injury on the frontal bone. The right shoulder shows some alterations, with a probable diagnosis of unreduced anterior dislocation of the humerus, with a consolidated fracture of the lesser tubercle of the humerus and secondary osteoarthritis in the glenoid cavity (Fig. 5). These injuries could be caused by a fall onto the hand or the elbow with the arm slightly abducted and externally rotated (Mac Rae 1988). A time lapse of 2-3 years since the accident would probably be needed to develop the bone changes observed. 


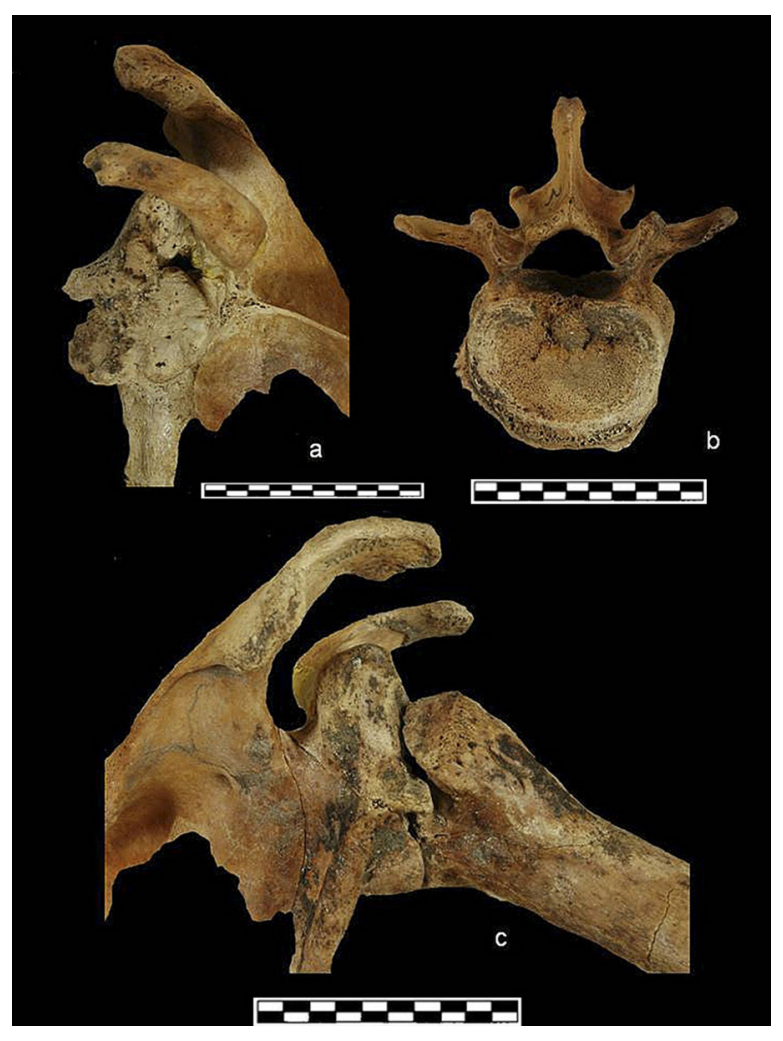

Fig. 5. Settlement of La Terrera del Reloj (Dehesa de Guadix, Granada). Case 3, 24 years-old male, burial $n$. $^{\circ}$ 2: a. Right scapula in anterior view; b. Lumbar vertebra with disc herniation and mild degenerative joint disease; c. Right humero-scapular joint. All photos: S. Jiménez-Brobeil.

With the humerus in anterior position, the arm would remain at a distance of $15-20 \mathrm{~cm}$ from the trunk when at rest. Given the condition of the joint, abduction would be limited to little more than $60^{\circ}$ and retropulsion and internal rotation movements would not be possible, although external rotation would be preserved (Kapandji 1984).

There are Schmorl's nodes in T5, T7, T9, T10, T11, T12, L1, L2 and L3 vertebrae. On the inferior surface of $\mathrm{T} 7$ and on the superior surface of L2, the depression produced by the pulpous nucleus reaches the medullar canal, implying a posterior disk hernia (Fig. 5b). L2, L4 and L5 show osteophytes, indicating the presence of osteoarthritis. In this young individual, the spinal lesions would be secondary to the shoulder injury, resulting from attempts to compensate for his lack of total shoulder abduction by rotating his trunk.
The condyles of both femurs and the patellar articular facets also show signs of osteoarthritis, and the lower extremity bones have pronounced marks corresponding to muscle development (Al Oumaoui et al. 2004). These findings indicate overloading of the knees, which could be a consequence of walking on the rugged and steep terrain at this site.

\section{Case 4}

This skeleton was discovered in 1986 at Fuente Amarga site (Galera, Granada). It comes from burial n. ${ }^{\circ} 9$ that contained the remains of a male and a female and several funerary goods: two pottery objects, a bronze dagger and a meat offering, denoting a medium social level (Fresneda et al. 1999). The male, in a good state of preservation, died when he was between 50 and 59 years old.

The male skeleton evidences severe dental disease, strong muscle development (Al Oumaoui et al. 2004) and five healed rib fractures $\left(6^{\text {th }}, 7^{\text {th }}\right.$ and $8^{\text {th }}$ on right side and $7^{\text {th }}$ and $8^{\text {th }}$ on the left). As in case 3, the right shoulder shows a series of alterations with the probable diagnosis of unreduced anterior dislocation of the humerus but without fracture of the lesser tubercle; a secondary osteoarthritis of the entire shoulder articulation can also be observed (Fig. 6a-c). In the right wrist, there is a well consolidated fracture of the distal third of the radius and another one of the ulnar styloid process, with a mild secondary osteoarthritis (Fig. 6d). The left wrist also shows a consolidated fracture with a slight deformation of the distal third of the radius, and some osteoarthritis on the distal head of the ulna. Because of post mortem fracture of the bone, it cannot be established whether the styloid process was also fractured. It cannot be determined whether these injuries occurred simultaneously or on separate occasions. The condition of the shoulder implies similar mobility limitations to those described in Case 3. The wrist fractures would have caused pain but little functional impotence, since they healed with minimum deformity.

The skeleton reveals mild osteoarthritis in the cervical sector of the spine $(\mathrm{C} 1-\mathrm{C} 4)$ and moderate osteoarthritis in the thoracic (T4-T12) and lumbar (L1-L5) sectors. T6, T7, T8, T9 and T10 vertebrae show signs of Schmorl's nodes. T5 


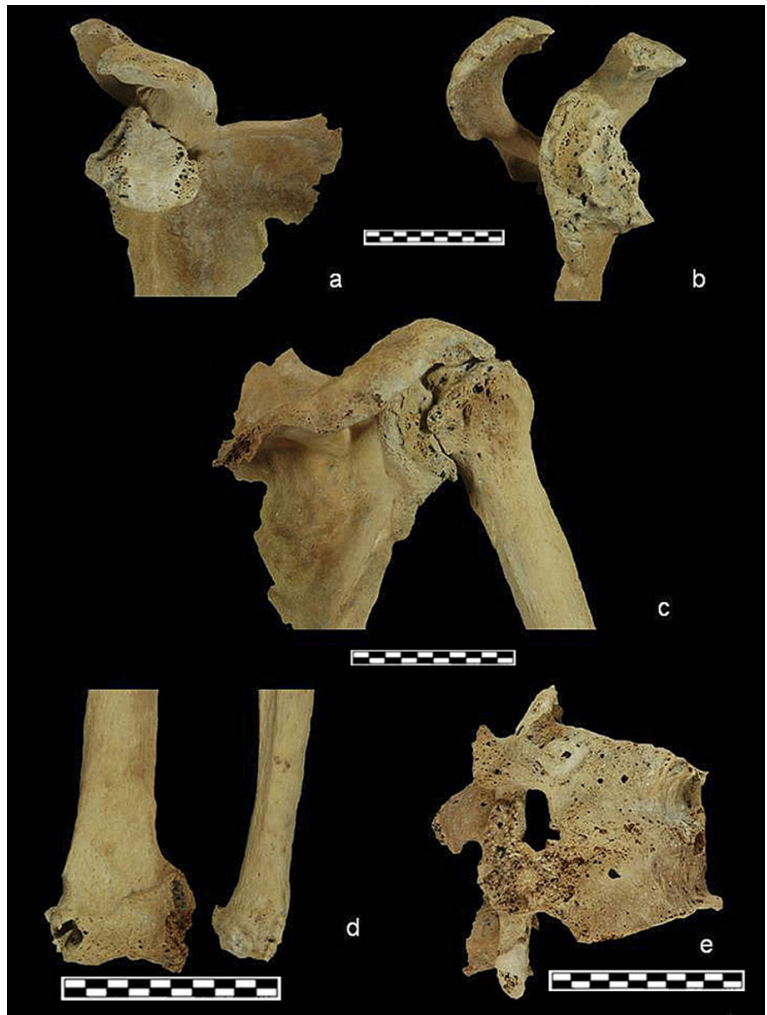

Fig. 6. Settlement of Fuente Amarga (Galera, Granada). Case 4, 50-59 years-old male, burial n. ${ }^{\circ}$ 9: a. Right scapula in anterior view; b. Right scapula in lateral view; c. Right humeroscapular joint; d. Detail of distal epiphysis of right radius and ulna; e. Fusion of T11 and T12 vertebrae due to compression fracture. All photos: S. Jiménez-Brobeil.

presents a compression fracture, while T11 and T12 form a block, with the vertebral bodies deformed into a wedge shape by another compression fracture (Fig. 6e). Although these lesions may be related to the age of this individual, they could be aggravated by his shoulder injury and corresponding mechanical incapacity. There are also signs of osteoarthritis in the hands, sacroiliac and coxo-femoral joints, knees and feet, which would be related to his age rather than to the traumatic lesions.

From the clinical standpoint, the four individuals described above present with physical impairment, but we cannot determine whether they were considered disabled by their own society (Metzler 1999; Shakespeare 1999). The mobility problems in Cases 1 and 2 would be aggravated by the environment at Castellón Alto, a stepped village on top of a hill. The major muscular de- velopment in their upper limbs indicates that they needed some kind of walking aid to move around, but they would not have been completely immobilized. The male (Case 1) may not have been able to perform agricultural or mining activities, which would require a normal capacity of movement, but this does not mean that he could not work in other ways, e.g., in craftwork. According to known activity patterns (Jiménez-Brobeil et al. 2004), Argaric females worked mainly in the domestic setting, and the woman (Case 2) should not have been prevented by her lesions from working in spinning, fabric-making, milling, cooking or any other activity susceptible of being performed sitting. A severe impairment of the right arm was detected in the males in Cases 3 and 4 . In Case 3, the spinal lesions suggest that he continued with his daily activities.

According to the funerary characteristics of their burials, all four individuals were considered members of their community at the time of their death, since they were buried beneath their homes with funerary goods, and the meat offerings indicate a commensality ritual in which family members participated.

\section{FINAL COMMENTS}

Out of a sample of more than 200 skeletons from the Argar Culture, only four individuals showed characteristics of physical impairment not related to age. Although they all had severe lesions, we are unable to determine whether they were considered disabled. However, they continued to live for some time after their injuries within a community that did not reject them although, perhaps, prevented a social rise. We know nothing of any care they might have received and we would be unable to establish the motivation for any care (e.g., compassion, interest, fear, love, etc.). We can, however, report that they were considered as members of their community at the time of their death, since they were buried according to the usual Argaric funerary rituals.

\section{BIBLIOGRAPHY}

Al Oumaoui, I. and Jiménez-Brobeil, S. A. 2003: "Lesiones traumáticas en un individuo de la Edad del Bronce". In J. Egocheaga (ed.): Biología de po- 
blaciones humanas: diversidad, tiempo, espacio. Universidad de Oviedo. Oviedo: 67-74.

Al Oumaoui, I.; Jiménez-Brobeil, S. A. and Souich, Ph. Du. 2004: "Markers of Activity Patterns in some Populations of the Iberian Peninsula". International Journal of Osteoarchaeology 14: 343-359.

Anderson, J. and Carden-Coyne, A. 2007: "Enabling the past: new perspectives in the History of disability". European Review of History 14 (4): 447-57.

Aranda Jiménez, G. and Esquivel Guerrero, J. A. 2007: "Poder y prestigio en las sociedades de la cultura de El Argar. El consumo de bóvidos y ovicápridos en los rituales de enterramiento". Trabajos de Prehistoria 64 (2): 95-118.

Battles, H. T. 2009: "Long bone bilateral asymmetry in the nineteenth-century Stirrup Court Cemetery collection from London, Ontario". Nexus: The Canadian Student Journal of Anthropology 21: 1-15.

Berkson, G. 2004: "Intellectual and Physical Disabilities in Prehistory and Early Civilization". Mental Retardation 42 (3): 195-208.

Buquet-Marcon, C.; Charlier, Ph. and Samzun, A. 2009: "A possible Early Neolithic amputation at ButhiersBoulancourt (Seine-et-Marne), France". Antiquity: Project Gallery 83 (322). In http://antiquity.ac.uk/ projgall/buquet322 (accessed 10-II-2010).

Byers, S. N. 2002: Introduction to forensic Anthropology. Allyn and Bacon. Boston.

Cámara, J. A. and Molina, F. 2006: "Selection of data, determinism and scientific relevance in interpretations of social development in the Late Prehistory of the Iberian Southeast". In P. Díaz-del-Río and L. García Sanjuan (eds.): Social Inequality in Iberian Late Prehistory. British Archaeological Reports International Series 1525, Archaeopress. Oxford: 21-35.

Castro Martínez, P. V.; Chapman, R. W.; Pili, S.; Lull, V.; Micó, R.; Rihuete, C.; Risch, R. and Sanahuja, M. E. 1993-1994: "Tiempos sociales de los contextos funerarios argáricos". Anales de Prehistoria y Arqueología 9-10: 77-105.

Chapman, R. 2003: Archaeologies of complexity. Routledge. London.

Chapman, R. 2008: "Producing inequalities: regional sequences in Later Prehistoric Southern Spain". Journal of World Prehistory 21: 195-260.

Cross, M. 1999: “Accessing the Inaccessible: Disability and Archaeology". Archaeological Review from Cambridge 15 (2): 7-30.

Darton, Y. 2010: "Scapular stress fracture: a palaeopathological case consistent with crutch use". International Journal of Osteoarchaeology 20: 113-121.

De Gusta, D. 2002: “Comparative skeletal pathology and the case for conspecific care in Middle Pleistocene hominids". Journal of Archaeological Science 29: $1435-1438$.
Dettwyler, K. A. 1991: "Can paleopathology provide evidence for 'compassion'?" American Journal of Physical Anthropology 84 (4): 375-384.

Dickel, D. N. and Doran, G. H. 1989: "Severe neural tube defect syndrome from the Early Archaic of Florida". American Journal of Physical Anthropology 80: 325-334.

Finlay, N. 1999: "Disabling Archaeology: An introduction". Archaeological Review from Cambridge 15 (2): 1-6.

Fresneda, E.; Rodríguez, M. O.; López, M. and Peña, J. M. 1999: "El asentamiento argárico de Fuente Amarga (Galera, Granada)". Actas del XXIV Congreso Nacional de Arqueología (Cartagena, 1997): 231-286. Cartagena.

Gracia, A.; Arsuaga, J. L.; Martínez, I.; Lorenzo, C.; Carretero, J. M.; Bermúdez de Castro, J. M. and Carbonell, E. 2009: "Craniosynostosis in the Middle Pleistocene human Cranium 14 from the Sima de los Huesos, Atapuerca, Spain". Proceedings of the National Academy of Sciences of the United Status of America 106 (16): 6573-6578.

Guilaine, J. and Zammit, J. 2002: El camino de la guerra. La violencia en la prehistoria. Barral. Barcelona.

Harding, A. F. 2000: European Societies in the Bronze Age. Cambridge University Press. Cambridge.

Hawkey, D. E. 1998: "Disability, compassion and the skeletal record: using musculoskeletal stress markers (MSM) to construct an osteobiography from Early New Mexico". International Journal of Osteoarchaeology 8: 326-340.

Jiménez-Brobeil, S. A.; Al Oumaoui, I. and Esquivel, J. A. 2004: “Actividad física según sexo en la Cultura Argárica. Una aproximación desde los restos humanos". Trabajos de Prehistoria 61 (2): 141-153.

Johnson, L. L.; Van Dyck, G. E.; Johnson, C. A.; Bays, B. M. and Gully, S. M. 1997: "The popliteal bursa (Baker's cyst): an arthroscopic perspective and the epidemiology". Arthroscopy 13: 66-72.

Kapandji, I. A. 1984. Cuadernos de fisiología articular. Toray-Masson. Barcelona.

Knüsel, C. J. 1999: “Orthopaedic disability: some hard evidence". Archaeological Review from Cambridge 15 (2): 31-53.

Koval, K. V. and Zuckerman, J. D. 2002: Handbook of Fractures. Lippincott Williams and Wilkins. Philadelphia.

Krogman, M. and Isçan, M. Y. 1986: The human skeleton in forensic medicine. Charles Thomas. Springfield.

Lieverse, A. R.; Metcalf, M. A.; Bazaliiskii, V. I. and Weber, A. W. 2008: "Pronounced bilateral asymmetry of the complete upper extremity: a case from the Early Neolithic Baikal, Siberia". International Journal of Osteoarchaeology 18: 219-239. 
Lordkipanidze, D.; Vekua, A.; Ferring, R.; Rightmire, G. P.; Agustí, J.; Kiladze, G.; Mouskhelishvili, A.; Inoradse, M.; Ponce de León, M. S.; Tappen, M. and Zollikofer, C. P. 2005: "Anthropology: the earliest toothless hominin skull”. Nature 434 (7034): 717-718.

Lull, V. 1983: La Cultura de El Argar, un modelo para el estudio de las formaciones económico-sociales prehistóricas. Akal. Madrid.

Lull, V. 2000: "Argaric society: death at home". Antiquity 74 (285): 581-590.

MacRae, R. 1988: Tratamiento práctico de fracturas. Interamericana-MacGraw Hill. Madrid.

Metzler, I. 1999: “The Palaeopathology of disability in the Middle Ages". Archaeological Review from Cambridge 15 (2): 55-67.

Molina, F. 1983: "Prehistoria". In F. Molina and J. Roldán (eds.): Historia de Granada de las primeras culturas al Islam. Don Quijote. Granada: 1-131.

Molina, M.; Aguayo, P.; Fresneda, E. and Contreras, F. 1986: "Nuevas investigaciones en yacimientos de la Edad del Bronce en Granada". Actas Congreso Homenaje Luis Siret (Cuevas del Almanzora, 1984): 353-360. Sevilla.

Molina, F. and Cámara, J. A. 2004: "La Cultura de El Argar en el área occidental del Sureste". In L. Hernández and M. Hernández (eds.): La Edad del Bronce en tierras valencianas y zonas limitrofes. Ayuntamiento de Villena. Alicante: 455-470.

Molina, F. and Cámara, J. A. 2009: "La cultura argárica en Granada y Jaén”. In M. Hernández, J. A. Soler and J. A. López (eds.): En los confines del Argar. Una cultura de la Edad del Bronce en Alicante. Museo Arqueológico de Alicante. Alicante: 196-223.

Molina, F.; Rodríguez-Ariza, M. O.; Jiménez-Brobeil, S. A. and Botella, M. 2003: "La sepultura $121 \mathrm{del}$ yacimiento argárico de El Castellón Alto (Galera, Granada)". Trabajos de Prehistoria 60 (1): 153-58.

Molleson, T. 1999: "Archaeological evidence for attitudes to disability in the past". Archaeological Review from Cambridge 15 (2): 69-77.

Oxenham, M. F.; Tillay, L.; Matsumura, H.; Nguyen, L. C.; Nguyen, K. T.; Nguyen, K. D.; Domett, K. and Huffer, D. 2009: "Paralysis and severe disability requiring intensive care in Neolithic Asia". Anthropological Science 117 (2): 107-112.
Pany, D. and Tescher-Nicola, M. 2007: "Klippel-Feil syndrome in an Early Hungarian period juvenile skeleton from Austria". International Journal of Osteoarchaeology 17: 403-415.

Phillips, S. M. and Sivilich, M. 2006: "Cleft palate: a case study of disability and survival in prehistoric North America". International Journal of Osteoarchaeology 16: 528-535.

Reid-Cunningham, A. R. 2009: "Anthropological Theories of Disability". Journal of Human Behavior in the Social Environment 19: 99-111.

Roberts, C. 1999: "Disability in the skeletal record: assumptions, problems and some examples". Archaeological Review from Cambridge 15 (2): 7997.

Roberts, C. and Manchester, K. 2007: The archaeology of Disease. Cornell University Press. Ithaca.

Rodríguez-Ariza, M. O. and Ruiz Sánchez, V. 1992: "Antracología y palinología del yacimiento argárico de Castellón Alto (Galera, Granada)". Anuario Arqueológico de Andalucía II: 169-176.

Shakespeare, T. 1999: "Commentary: Observations on disability and Archaeology". Archaeological Review from Cambridge 15 (2): 99-101.

Siret, E. and Siret L. 1890: Las primeras edades del metal en el sudeste de España. Imprenta Henrich y Cía. Barcelona.

Suchey, J. M. and Brooks, S. T. 1988: Skeletal age determination on the male os pubis. France Casting. Bellvue.

Tarlow, S. 2000: "Emotion in Archaeology". Current Anthropology 41 (5): 713-746.

Thorpe, N. 2008: "The prehistory of Disability and Deformity". 6 World Archaeological Congress (Dublin, 2008). http://www.wac6.org/livesite/precirculated/2800_precirculated.pdf (accessed 16-XI2009).

Trinkaus, E. and Zimmerman, M. R. 1982: "Trauma among the Shanidar Neandertals". American Journal of Physical Anthropology 57 (1): 61-76.

Van Der Sanden, W. A. B. 1996: Trough Nature to Eternity. The Bog Bodies of Northwest Europe. Batavian Lion International. Amsterdam.

Winzer, M. 1997: "Disability and Society before the Eighteenth Century". In L. J. Davies (ed.): The Disability Study Reader. Routledge. New York and London: 75-109. 